\title{
Attenuation of Mercury Phytotoxicity with a High Nutritional Level of Nitrate in Alfalfa Plants Grown Hydroponically
}

\section{Sandra Carrasco-Gil}

Universidad Autónoma Madrid

Cristina Ortega-Villasante

Universidad Autónoma Madrid

Juan Sobrino-Plata

Universidad Autónoma Madrid

Ángel Barón-Sola

Universidad Autónoma Madrid

Rocío Millán

Medioambientales y Tecnológicas, Avd. Complutense

Luis E. Hernandez ( $\square$ luise.hernandez@uam.es )

Universidad Autonoma of Madrid https://orcid.org/0000-0003-3492-5813

\section{Research Article}

Keywords: Alfalfa, mercury, nitrate nutrition, oxidative stress, tolerance

Posted Date: August 19th, 2021

DOl: https://doi.org/10.21203/rs.3.rs-771412/v1

License: (9) (i) This work is licensed under a Creative Commons Attribution 4.0 International License. Read Full License 


\section{Abstract}

Background and aims Mercury $(\mathrm{Hg})$ is one of the most dangerous pollutant heavy metals to the environment, which causes several toxic effects in plants upon accumulation, such as induction of oxidative stress. Nitrogen $(\mathrm{N})$ is one of the most limiting macronutrient for plants, being mostly assimilated as $\mathrm{NO}_{3}{ }^{-}$which is reduced to $\mathrm{NO}_{2}{ }^{-}$by the enzyme nitrate reductase (NR), prior its reduction to $\mathrm{NH}_{4}^{+}$.

Methods We studied the physiological alterations caused by $\mathrm{Hg}(0,6$ and $30 \mu \mathrm{M})$ in alfalfa plants grown at two different levels of $\mathrm{NO}_{3}^{-}$: low, $(2 \mathrm{mM} ; \mathrm{LN})$, and high (12 mM; HN) for one week using a semihydroponic culture system.

Results Several parameters of oxidative stress such as lipid peroxidation, chlorophyll content, biothiol concentration and, ascorbate peroxidase (APX) and glutathione reductase (GR) activity showed that HN plants were less affected by $\mathrm{Hg}$. Nitrate reductase activity and $\mathrm{NO}_{3}{ }^{-}$concentration was altered under $\mathrm{Hg}$ stress, with lower impact in plants nourished with high $\mathrm{NO}_{3}{ }^{-}$.

Conclusions Our results highlight the importance of the nitrogen nutritional status to improve tolerance to toxic metals like $\mathrm{Hg}$.

\section{Introduction}

Mercury is one of the most hazardous pollutants released to the environment by diverse anthropogenic activities like mining, as occurs in the Almadén district (Ciudad Real, Spain), where weathered litter and metallurgy wastes are spread in soils and sediments (Esbrí et al. 2010). Cessation of the production of $\mathrm{Hg}$ has imposed the necessity to impulse other economic activities, such as agriculture and farming, which are undermined by the accumulation of $\mathrm{Hg}$ in local soils (Sierra et al. 2008). On other hand, the ability of plants to extract metals from the soil can be exploited to clean up polluted soils by using phytoremediation technologies. In this sense, intense research is conducted to understand tolerance mechanism in plants that might help to optimise such promising clean techniques (Clemens et al. 2002).

The divalent cation $\left(\mathrm{Hg}^{2+}\right)$ is predominant in well aerated agricultural soils, among other $\mathrm{Hg}$ chemical forms (Han et al. 2006). Exposure of plants to $\mathrm{Hg}^{2+}$ lead to numerous physiological disorders and injuries (Zhou et al. 2007), including drastic growth inhibition, alteration of photosynthesis, mitochondrial respiration, and obstruction of water flow through the inhibition of plasma membrane aquaporins (Patra and Sharma 2000; Cargnelutti et al. 2006; Israr and Sahi 2006; Shiyab et al. 2009). One of the earliest symptoms of $\mathrm{Hg}$ toxicity is the induction of oxidative stress, resulting in oxidation of membrane lipids and severe alteration of membrane integrity (Ortega-Villasante et al. 2005), causing cell poisoning and death (Ortega-Villasante et al. 2007). To counteract this cellular redox imbalance, plants possess antioxidant defences including enzymes like ascorbate peroxidase (APX) and glutathione reductase (GR), and redox metabolites like glutathione (GSH; үGlu-Cys-Gly)(Sharma and Dietz 2009), which also operate 
under Hg stress (Cho and Park 2000; Cargnelutti et al. 2006; Elbaz et al. 2010). However, even under relative low $\mathrm{Hg}$ concentrations ( 1 to $3 \mu \mathrm{M}$ ), the activity of these antioxidant enzymes usually drops (Ortega-Villasante et al., 2007; Zhou et al., 2007; Sobrino-Plata et al., 2009; Elbaz et al., 2010). In particular, GR is extremely sensitive to $\mathrm{Hg}$ accumulated in the roots of several plant species (SobrinoPlata et al. 2009, 2013), and has been proposed as specific biomarker of Hg phytotoxicity. This was confirmed in Arabidopsis mutant plants with limited cellular concentration of GSH, which showed severe $\mathrm{Hg}$ toxic symptoms and a drastic GR activity inhibition (Sobrino-Plata et al. 2021). Therefore, tolerance to $\mathrm{Hg}$ highly depends on the levels of GSH and derived biothiols, including phytochelatins (PCs), a family of thiol-rich peptides with general ( $\mathrm{GGlu}-\mathrm{Cys})_{n}$-Gly(-Ala) structure (where $n$ varies between the range 2-5) (Serrano et al. 2015).

Nitrogen $(\mathrm{N})$ is a very limiting macronutrient, normally assimilated as nitrate $\left(\mathrm{NO}_{3}{ }^{-}\right)$. The assimilation of $\mathrm{NO}_{3}{ }^{-}$comprises its reduction in a two-step process, firstly it is reduced to $\mathrm{NO}_{2}{ }^{-}$by the cytosolic enzyme nitrate reductase (NR), and then to $\mathrm{NH}_{4}{ }^{+}$thanks to the plastidial enzyme nitrite reductase (NiR)

(Yoneyama and Suzuki 2019). $\mathrm{NH}_{4}{ }^{+}$is then incorporated to organic acids to form amino acids, through a series of amination and transamination reactions in a complex assimilatory pathway where NR is the limiting step (Campbell 1999). Heavy metal polluted areas are commonly waste lands with low $\mathrm{N}$ availability, so nitrogen fertilizers must be applied to improve the biomass yield of plants cultivated for phytoremediation purposes in those areas (Wong 2003). On the other hand, the addition of organic matter and NPK inorganic fertilizers containing $\mathrm{NO}_{3}{ }^{-}$is a common agricultural practice (Barrutia et al. 2009). Therefore, it is important to study the relation between $\mathrm{NO}_{3}{ }^{-}$nutritional status and heavy metals toxicity. Toxic heavy metals may disturb $\mathrm{N}$ metabolic system, inhibiting NR activity as observed under Cd stress (Hernandez et al. 1996; Gouia et al. 2000; Chaffei et al. 2004). Indeed, pea plants treated with 50 $\mu \mathrm{M}$ Cd suffered a severe diminution in $\mathrm{NO}_{3}{ }^{-}$assimilation, affecting $\mathrm{NO}_{3}{ }^{-}$and $\mathrm{K}$ uptake and $\mathrm{NO}_{3}{ }^{-}$ reduction by NR (Hernández et al. 1997). Similar results were obtained in bean and tomato plants exposed to $\mathrm{Cd}$, where the assimilation of $\mathrm{NO}_{3}{ }^{-}$and $\mathrm{NH}_{4}{ }^{+}$was compromised by metal stress (Gouia et al. 2000; Chaffei et al. 2004). On the other hand, recent studies tested the effects of $\mathrm{N}$ supply on Cd uptake in plants, showing the beneficial effect of $\mathrm{N}$ fertilization (Gao et al. 2010; Hussain et al. 2020). Under $\mathrm{N}$ starvation, there were stronger Cd phytotoxic symptoms in Hordeum vulgare, in parallel to the upregulation of phytochelatin synthase (PCS) and NRAMP metal transporters gene expression, with modest changes in the expression of oxidative stress related genes (Finkemeier et al. 2003).

In consequence, $\mathrm{N}$ nutritional status seems to modulate toxic metals tolerance in plants (Hussain et al. 2020). It should be noted that the information available about the interaction between $\mathrm{NO}_{3}{ }^{-}$nutrition status and $\mathrm{Hg}$ phytotoxicity is almost null, and would be useful for designing improved phytoremediation procedures in Hg-polluted soils. Therefore, we aimed to characterise the responses of alfalfa plants with low and high $\mathrm{NO}_{3}{ }^{-}$nutritional status to $\mathrm{Hg}$ exposure in a semi-hydroponic system using perlite as inert substrate. These experiments will help to understand the effect of $\mathrm{NO}_{3}{ }^{-}$fertilization on $\mathrm{Hg}$ tolerance, by analysing $\mathrm{Hg}$ distribution in plant, oxidative stress and $\mathrm{N}$ assimilation parameters. 


\section{Materials And Methods}

Plant material, growth conditions and treatments

Alfalfa (Medicago sativa cv. Aragon) seedlings were surface sterilized for 5 min in $5 \%(v / v)$ commercial bleach. After rinsing several times with sterile water, seeds were soaked overnight at $4^{\circ} \mathrm{C}$ and germinated on $1.5 \%(\mathrm{w} / \mathrm{v})$ agar in square Petri dishes $(10 \times 10 \mathrm{~mm})$, in complete darkness for $48 \mathrm{~h}$ at $28^{\circ} \mathrm{C}$. Homogeneous selected seedlings were transferred to a semi-hydroponic system using a perlite inert substrate in plastic trays submerged in two modified Hoagland nutrient solutions (Ortega-Villasante et al. 2005): One of them with low $\mathrm{NO}_{3}{ }^{-}$concentration ( $\mathrm{LN} ; 2 \mathrm{mM}$ ) (macronutrients [mM]: $1.0 \mathrm{KH}_{2} \mathrm{PO}_{4}, 0.5$ $\left.\mathrm{MgSO}_{4}, 0.1 \mathrm{NaCl}, 0.9 \mathrm{Ca}\left(\mathrm{NO}_{3}\right)_{2}, 0.63 \mathrm{KNO}_{3}, 0.47 \mathrm{Mg}\left(\mathrm{NO}_{3}\right)_{2}\right)$ and the other one with high $\mathrm{NO}_{3}{ }^{-}$ concentration ( $\mathrm{HN} ; 12 \mathrm{mM}$ ) (macronutrients [mM]: $1.0 \mathrm{KH}_{2} \mathrm{PO}_{4}, 0.5 \mathrm{MgSO}_{4}, 0.1 \mathrm{NaCl}, 5.4 \mathrm{Ca}\left(\mathrm{NO}_{3}\right)_{2}, 3.8$ $\left.\mathrm{KNO}_{3}, 2.8 \mathrm{Mg}\left(\mathrm{NO}_{3}\right)_{2}\right)$; both supplemented with micronutrients [ $\left.\mu \mathrm{M}\right]: 45.0 \mathrm{Fe}(\mathrm{EDDHA}), 18.0 \mathrm{MnSO}_{4}, 3.0$ $\left.\mathrm{ZnSO}_{4}, 6.0 \mathrm{CuSO}_{4}, 23.5 \mathrm{H}_{3} \mathrm{BO}_{3}, 2.0 \mathrm{Mo}_{7} \mathrm{O}_{24}\left(\mathrm{NH}_{4}\right)_{6}\right)$. The plants grew for 12 days in a controlled environment chamber ( $16 \mathrm{~h}$ light (lamps of $120 \mathrm{Wm}^{-2}$ )/ $8 \mathrm{~h}$ darkness) at $25 / 18^{\circ} \mathrm{C}$ respectively and relative humidity, 75\%. 0, 6 and $30 \mu \mathrm{M} \mathrm{Hg}$ was then supplied as $\mathrm{HgCl}_{2}$, and plants were collected after 7 days. Samples were thoroughly washed in deionized $\mathrm{H}_{2} \mathrm{O}$, fresh weight measured and stored at $-80^{\circ} \mathrm{C}$ until analysis.

Mercury analysis

Solid samples of roots and shoots were air dried and ground with mortar and pestle. Dried plant material (100 mg) was acid digested in $2 \mathrm{~mL}$ of the digestion mixture $\left(\mathrm{HNO}_{3}: \mathrm{H}_{2} \mathrm{O}_{2}, \mathrm{H}_{2} \mathrm{O}, 0.6: 0.4: 1 \mathrm{v}: \mathrm{v}\right)$ in an autoclave (Presoclave- 75 Selecta, Barcelona, Spain) at $120^{\circ} \mathrm{C}$ and $1.5 \mathrm{~atm}$ for $30 \mathrm{~min}$ (Ortega-Villasante et al. 2007). Mercury concentration was measured by atomic absorption spectrophotometry using the Advanced Mercury Analyser 254 Leco (St. Joseph, Michigan, MI, USA) with a detection limit of $0.5 \mathrm{ug} \mathrm{kg}^{-}$ 1. Certified Reference Materials (CRM) were used to determine the accuracy of the measurements and validation.

Nitrogen in plants

The nitrogen $(\mathrm{N})$ in plant tissue was determined by Kjeldahl digestion, performed in a wet digestor system B-440 (Buchi, Switzerland). Dry plant material was ground to powder using a mortar and pestle, and 0.05 $\mathrm{g}$ was transferred to the digestion tubes together with $10 \mathrm{ml}$ of $98 \% \mathrm{H}_{2} \mathrm{SO}_{4}(\mathrm{v} / \mathrm{v})$ and $10 \mathrm{~g}$ of $\mathrm{K}_{2} \mathrm{SO}_{4}$. The solution was heated at $410{ }^{\circ} \mathrm{C}$ for $1.5 \mathrm{~h}$, and cooled for $30 \mathrm{~min}$. $\mathrm{NH}_{4}{ }^{+}$was distilled after the addition of 25 $\mathrm{ml}$ of $32 \% \mathrm{NaOH}\left(\mathrm{v} / \mathrm{w}\right.$ ) in a $\mathrm{K}-355$ distillation unit (Buchi, Switzerland). The concentration of $\mathrm{NH}_{3}$ released in the resulting alkaline mixture was calculated by back titration of $2 \% \mathrm{H}_{3} \mathrm{BO}_{3}(\mathrm{v} / \mathrm{v})$ buffer adjusted to $\mathrm{pH}$ 4.65 with $0.02 \mathrm{M} \mathrm{HCl}$, following the specifications of a KF Titrino Plus 870 equipment (Metrohm, Switzerland).

Lipid peroxidation and chlorophyll analysis 
Lipid peroxidation was estimated by measuring the concentration of the by-product malondialdehyde, which reacts with thiobarbituric acid. The resulting chromophore absorbs at $535 \mathrm{~nm}$, and the concentration was calculated directly from the extinction coefficient of $1.56 \times 10^{5} \mathrm{M}^{-1} \mathrm{~cm}^{-1}$ (RellánÁlvarez et al. 2006). Ground frozen tissue $(0.1 \mathrm{~g})$ was transferred to a screw-capped $1.5 \mathrm{ml}$ Eppendorf tube, and homogenized in $1 \mathrm{ml}$ of TCA-TBA-HCl reagent (15\% (w/v) trichloroacetic acid (TCA), $0.37 \%$ (w/v) 2-thiobarbituric acid (TBA), $0.25 \mathrm{M} \mathrm{HCl}$, and $0.01 \%$ buthylated hydroxytoluene). Samples were incubated at $90^{\circ} \mathrm{C}$ for $30 \mathrm{~min}$, chilled in ice, and centrifuged at $12000 \mathrm{~g}$ for $10 \mathrm{~min}$. Absorbance was measured in a UV-2401 PC spectrophotometer (Shimadzu, Tokyo, Japan). For chlorophyll (Chl) determination, $0.05 \mathrm{~g}$ of frozen leaves were homogenized with $10 \mathrm{ml} 80 \%(\mathrm{v} / \mathrm{v})$ acetone using a mortar and pestle. Homogenates were filtered through a paper filter and absorbance was measured in a UV-2401 PC spectrophotometer (Shimadzu) at 645 and $663 \mathrm{~nm}$. Total chlorophyll concentration was calculated according to the procedure of Porra (2002).

Analysis of biothiols

$0.1 \mathrm{~g}$ of frozen tissue was ground with $300 \mu \mathrm{l}$ of $0.25 \mathrm{~N} \mathrm{HCl}$, the homogenate centrifuged for $15 \mathrm{~min}$ at $12000 \mathrm{~g}$ and $4^{\circ} \mathrm{C}$, and the clear supernatant was transferred to a boron-silica glass injection vial. $100 \mu \mathrm{l}$ were injected in a Mediterranea Sea18 column ( $5 \mu \mathrm{m}, 250 \times 4.6 \mathrm{~mm}$; Teknokroma, Spain), and biothiols were eluted using an Agilent 1200 HPLC system (Santa Clara, CA, USA) with the elution program and detection procedure with Ellman's reagent (5,5-dithio-bis ( 2 nitrobenzoic acid) at $412 \mathrm{~nm}$ absorbance as described by Ortega-Villasante et al. (2005). Biothiol concentration was calculated relative to the acetyl cysteine (N-AcCys) internal standard $(25 \mathrm{nmol})$. Several biothiol standards were prepared in analyticalgrade type I water (Milli-Q Synthesis, Millipore), diluted to $0.1 \mathrm{mM}$ and injected alone or as internal standards for retention time peak identification, of the following compounds: $\mathrm{GSH}$, homoglutathione (hGSH), cysteine (Cys), homophytochelatin-2 ( $\mathrm{Y}$-(Glu-Cys) ${ }_{2}-\mathrm{Ala}_{\mathrm{A}} \mathrm{hPC}_{2}$ ), and hompphytochelatin-3 ( $\mathrm{Y}$-(GluCys) ${ }_{3}-\mathrm{Ala} \mathrm{hPC}_{3}$ ).

Determination of nitrate reductase activity in vitro

The in vitro nitrate reductase (NR) activity was analysed following the procedure described by Ramón et al. (1989). Intact frozen tissue $(0.5 \mathrm{~g})$ was homogenised in $1 \mathrm{ml}$ or $0.5 \mathrm{ml}$ enzymatic Extraction Solution respectively for shoot and root, freshly prepared by mixing $10 \mathrm{ml}$ extraction buffer $(30 \mathrm{mM} 3-(\mathrm{N}$ morpholino) propanesulfonic acid (MOPS) at pH 7.5, $5 \mathrm{mM} \mathrm{Na}_{2}$-EDTA, $10 \mathrm{mM}$ DTT, $10 \mathrm{mM}$ ascorbic acid, 0.6\% PVP, $10 \mu \mathrm{l} 100 \mathrm{mM}$ PMSF) and $1 \mathrm{ml}$ protease inhibitors cocktail Sigma-Aldrich (P2714; St. Louis, MO, USA). After centrifugation ( $14000 \times \mathrm{g})$ for $15 \mathrm{~min}$ at $4^{\circ} \mathrm{C}$, the supernatant was kept in ice until NR activity assay, measured by adding $0.1 \mathrm{ml}$ of enzymatic extract, $0.1 \mathrm{ml} 100 \mathrm{mM} \mathrm{KNO}_{3}, 0.5 \mathrm{ml}$ reaction buffer (100 mM KH${ }_{2} \mathrm{PO}_{4} / \mathrm{K}_{2} \mathrm{HPO}_{4}, 1 \mathrm{mM}$ EDTA, pH 7.5) and $0.1 \mathrm{ml}$ of $1 \mathrm{mg} \mathrm{ml}^{-1} \mathrm{NADH}$. Formed $\mathrm{NO}_{2}{ }^{-}$was analysed after $15 \mathrm{~min}$ incubation at $28^{\circ} \mathrm{C}$, and the reaction was stopped by the addition of $2 \mathrm{ml}$ of freshly prepared colorimetric reagent $(1 \%(\mathrm{v} / \mathrm{v})$ sulphanilamide in $3 \mathrm{M} \mathrm{HCl}$, and $0.02 \%(\mathrm{w} / \mathrm{v}) \mathrm{N}-(1$-naphthyl) ethylenediamide dihydrochloride mixed in a 1:1 ratio). Samples were centrifuged at $10000 \mathrm{~g}$ for $15 \mathrm{~min}$, and absorbance read at $540 \mathrm{~nm}$ using a UV-2401 PC spectrophotometer (Shimadzu). 
Glutathione reductase (GR) and ascorbate peroxidise (APX) activities were determined in gel after separation of protein extracts by non-denaturing electrophoresis in $10 \%$ polyacrylamide gels. Extracts were prepared from $0.5 \mathrm{~g}$ of intact frozen samples in $1 \mathrm{ml}$ enzymatic Extraction Solution (see above). After centrifugation (14000 g) for $15 \mathrm{~min}$ at $4^{\circ} \mathrm{C}$, the supernatant was stored as single use $100-200 \mu \mathrm{l}$ aliquots at $80^{\circ} \mathrm{C}$. Protein concentration in the extracts was preliminarily determined with the BioRad Protein Assay reagent (BioRad, Hercules, CA, USA), and the final loading for activity staining was adjusted after denaturing gel electrophoresis and Coomassie-blue staining (Laemmli 1970). Protein loading for GR and APX analysis was $15 \mu \mathrm{g}$ and $5 \mu \mathrm{g}$ of shoot and root extracts, respectively. Gel slabs were incubated in GR staining solution ( $250 \mathrm{mM}$ Tris-HCl buffer at pH 7.5, supplemented with $0.2 \mathrm{mg} \mathrm{ml}^{-1}$ thizolyl blue tetrazolium bromide, $0.2 \mathrm{mg} \mathrm{ml}^{-1}$ 2,6-dichlorophenol indophenol, $0.5 \mathrm{mM} \mathrm{NADPH}$ and $3.5 \mathrm{mM}$ oxidised glutathione (Sobrino-Plata et al. 2009). APX was detected as described by Jiménez et al. (1998). Gel slabs were incubated for 20 min with $2 \mathrm{mM}$ ascorbate and $2 \mathrm{mM} \mathrm{H}_{2} \mathrm{O}_{2}$ in $50 \mathrm{mM}$ Na-phosphate buffer at $\mathrm{pH} 7.0$, and APX were revealed after incubation with $0.5 \mathrm{mM}$ nitroblue tetrazolium (NBT) and $10 \mathrm{mM}$ TEMED in $50 \mathrm{mM}$ phosphate buffered at $\mathrm{pH} 7.8$.

\section{Protein immunodetection}

Proteins of interest were immunodetected after denaturing gel electrophoresis and Western-blotting (Laemmli 1970), using a-cytosolic APX (AS06180), a-GR (AS06181), a-NR (AS08310), a-NTR1.1 (AS122611), and a-NTR2.1 (AS122612) (Agrisera, Vännäs, Sweden). After electrophoresis (20 $\mu \mathrm{g}$ total protein), proteins were blotted onto a nitrocellulose membrane (BioTraceNT Pall Corporation, East Hills, NY, USA) using a semi-dry procedure (Trans Blot SD Semi-Dry Electrophoretic Transfer Cell, BioRad), after incubation in transfer buffer ( $48 \mathrm{mM}$ Tris-HCl, $39 \mathrm{mM}$ glycine, $1.3 \mathrm{mM}$ SDS, and 20\% methanol at pH 8.3). Membranes were blocked with $1 \%$ bovine serum albumin in Tris-buffer-saline (TBS), and incubated overnight at $4^{\circ} \mathrm{C}$ with the primary antibodies diluted $1 / 1000$. Then, membranes were incubated with the secondary antibody (a-rabbit IgG goat:horseradish peroxidase, Ref. A00160, GenScript, Piscataway, NJ, USA) diluted $1 / 10000$ for $2 \mathrm{~h}$. Proteins were detected by incubating with LumiSensor ${ }^{\text {TM }}$ Chemiluminescent HRP Substrate Kit (Ref. L00221V300, GenScript).

Statistical analysis

Results were mean of at least three independent replicates \pm standard deviation, with significant differences between treatments at $p<0.05$. ANOVA statistical analysis was performed with post-hoc Duncan test using SPSS 17.0 (SPSS Inc., Chicago, USA). For image analysis of in gel enzymatic activity and Western-blot immunodetection, images were obtained with a ChemiDoc ${ }^{T M}$ XRS + System (BioRad). Band intensity were measured and relative fold-change to control samples was calculated. Only relevant differences of gels representative of three independent assays are shown.

\section{Results}


Toxicity caused by $\mathrm{Hg}$ was evaluated via determination of lipid peroxidation, biometric parameters and chlorophyll concentration (Fig. 1). In shoots, neither the $\mathrm{NO}_{3}$ - supply nor $\mathrm{Hg}$ exposure produced significant changes in fresh weigh. However, $\mathrm{Hg}$ exposure produced reduced root biomass, especially when $\mathrm{NO}_{3}-$ supplementation was low (LN plants, Fig. $1 \mathrm{~A}$ ). In control plants, low $\mathrm{NO}_{3}-$ supply increased lipid peroxidation compared to high $\mathrm{NO}_{3}-$ especially significant in roots (Fig. 1B). Despite $\mathrm{Hg}$ treatments, roots of HN plants showed similar lipid peroxidation values, while MDA content clearly increased in a metal concentration manner (Fig. 1B). However, plants of LN root lipid peroxidation remained at higher despite $\mathrm{Hg}$ treatments (Fig. 1B). Chlorophyll concentration was not affected by $\mathrm{Hg}$ exposure in $\mathrm{HN}$ plants and only decreased slightly in plants exposed $30 \mu \mathrm{M} \mathrm{Hg}$ and nourished with low $\mathrm{NO}_{3}-$ (Fig. 1C).

The concentration of biothiols was determined to assess the effects of $\mathrm{NO}_{3}{ }^{-}$nutrition on the accumulation of GSH, hGSH, PCs and hPCs (Carrasco-Gil et al. 2011). As shown in Table 1, hGSH was the major biothiol in alfalfa being its shoot concentration 2-3 times higher than in roots. Significant differences in hGSH values were the only found between $L N$ and $H N$ in roots of plants exposed to $6 \mu \mathrm{M}$ but not $30 \mu \mathrm{M} \mathrm{Hg}$, suggesting that $\mathrm{NO}_{3}{ }^{-}$concentration produced minimal changes in the biothiols content. PCs, hPCs, and cysteine (Cys, in shoots), were not detected in our experimental conditions, probably due to analytical drawbacks (see discussion).

Table 1

Non-protein thiols content (nmol g- 1 FW) in shoot and root of Medicago sativa grown in low NO3- (LN; 2 $\mathrm{mM}$ ) and high NO3- (HN; $12 \mathrm{mM}$ ) treated with 0 (control), 6 and $30 \mu \mathrm{M} \mathrm{Hg}$ for 7 days. Concentration of each thiol peptide was calculated equivalent to the internal standard of N-Ac-Cys. Data are average of three independent replicates $( \pm S D)$.

\begin{tabular}{|c|c|c|c|c|c|c|c|}
\hline & & ROOT & & & SHOOT & & \\
\hline Thiol & $\mathrm{NO}_{3}^{-}$ & Control & $6 \mu \mathrm{M} \mathrm{Hg}$ & $30 \mu \mathrm{M} \mathrm{Hg}$ & Control & $6 \mu \mathrm{M} \mathrm{Hg}$ & $30 \mu \mathrm{M} \mathrm{Hg}$ \\
\hline \multirow[t]{2}{*}{ Cys } & LN & $\begin{array}{l}21.6 \pm \\
12.2\end{array}$ & $16.1 \pm 3.1$ & $25.0 \pm 6.8$ & nd & nd & nd \\
\hline & $\mathrm{HN}$ & $17.4 \pm 2.8$ & $16.8 \pm 4.5$ & $25.5 \pm 7.1$ & nd & nd & nd \\
\hline \multirow[t]{2}{*}{ hGSH } & LN & $\begin{array}{l}64.3 \pm \\
10.4^{\mathrm{a}}\end{array}$ & $\begin{array}{l}64.1 \pm \\
18.3^{\mathrm{a}}\end{array}$ & $\begin{array}{l}93.7 \pm \\
21.5^{a, b}\end{array}$ & $\begin{array}{l}192.7 \pm \\
63.5\end{array}$ & $\begin{array}{l}178.6 \pm \\
64.3\end{array}$ & $\begin{array}{l}192.8 \pm \\
61.4\end{array}$ \\
\hline & HN & $\begin{array}{l}69.4 \pm \\
33.0^{\mathrm{a}}\end{array}$ & $\begin{array}{l}127.7 \pm \\
44.1^{b}\end{array}$ & $\begin{array}{l}102.6 \pm \\
19.5^{a, b}\end{array}$ & $\begin{array}{l}193.9 \pm \\
38.9\end{array}$ & $\begin{array}{l}205.1 \pm \\
69.7\end{array}$ & $\begin{array}{l}224.7 \pm \\
92.5\end{array}$ \\
\hline \multirow[t]{2}{*}{ GSH } & LN & $\begin{array}{l}31.7 \pm \\
15.7\end{array}$ & $29.0 \pm 9.9$ & $39.8 \pm 9.7$ & $\begin{array}{l}27.9 \pm \\
10.9\end{array}$ & $25.8 \pm 9.5$ & $18.9 \pm 5.4$ \\
\hline & HN & $\begin{array}{l}27.9 \pm \\
12.2\end{array}$ & $29.5 \pm 11.5$ & $29.9 \pm 9.9$ & $41.3 \pm 6.2$ & $21.1 \pm 7.2$ & $18.8 \pm 3.5$ \\
\hline \multicolumn{8}{|c|}{ n.d: no detected } \\
\hline \multicolumn{8}{|c|}{ Different letters denote significant differences between treatments at $p<0.05$. } \\
\hline
\end{tabular}


Mercury treatments caused significant $\mathrm{Hg}$ accumulation in shoots and roots, increasing concomitantly with $\mathrm{Hg}$ doses in the nutrient solution. Root $\mathrm{Hg}$ concentration was between 10 and 30 times higher than in shoot (Fig. 2). It should be noted that control shoot accumulated between 7 and $10 \mu \mathrm{g} \mathrm{g}^{-1}$ of $\mathrm{Hg}$ (two to three times lower than plants exposed to $6 \mu \mathrm{M} \mathrm{Hg}$ ), probably caused by growth media splashing and/or volatilisation over the $7 \mathrm{~d}$ of metal treatment. Low $\mathrm{NO}_{3}-$ supply caused increased $\mathrm{Hg}$ accumulation both in roots and in shoots, indicating that nitrate nutritional status affects $\mathrm{Hg}$ accumulation in plants.

To characterise the effect of $\mathrm{Hg}$ on $\mathrm{N}$ nutrition, we analysed the concentration of $\mathrm{NO}_{3}-$ and total content of $\mathrm{N}$ (Fig. 3). As expected, $\mathrm{NO}_{3}-$ concentration was higher in $\mathrm{HN}$ than in $\mathrm{LN}$ plants, both in shoots and roots (Fig. 3A). Exposure to $\mathrm{Hg}$ decreased the concentration of $\mathrm{NO}_{3}-$ in shoot of $\mathrm{HN}$ plants treated with $\mathrm{Hg}$, and only in roots of plants exposed to $30 \mu \mathrm{M} \mathrm{Hg}$. Similarly, $\mathrm{N}$ content was also higher in plants grown with $\mathrm{HN}$ than those nourished with $\mathrm{LN}$. In the presence of $6 \mu \mathrm{M} \mathrm{Hg}$, the amount of $\mathrm{N}$ per plant varied slightly, and decreased significantly in shoot of alfalfa treated with $30 \mu \mathrm{M} \mathrm{Hg}$, particularly in LN plants (Fig. 3B). However, total $\mathrm{N}$ concentration in roots showed minimal (HN) or no (LN) changes in response to $\mathrm{Hg}$ treatments, with inconsistent diminution in plants grown with $\mathrm{HN}$ and $6 \mu \mathrm{M} \mathrm{Hg}$, whereas values were not significantly different in plants exposed to $30 \mu \mathrm{M} \mathrm{Hg}$..

$\mathrm{NR}$ activity reflected a similar behaviour as $\mathrm{NO}_{3}-$ and $\mathrm{N}$ total concentration in plants, being higher in $\mathrm{HN}$ than LN plants (Fig. 4). In overall, shoot NR activity was three-times greater than in root, indicating that shoots assimilate the largest proportion of $\mathrm{NO}_{3}-$ in alfalfa. Shoot NR activity was modestly affected by $\mathrm{Hg}$ in $\mathrm{HN}$ plants, increasing significantly only in LN plants exposed to $30 \mu \mathrm{M} \mathrm{Hg}$. However, some remarkable changes were detected in roots: NR activity augmented in plants exposed to $6 \mu \mathrm{M} \mathrm{Hg}$, especially if nourished with high $\mathrm{NO}_{3}-$ (Fig. 4). Finally, root NR activity decreased almost to control values with $30 \mu \mathrm{M} \mathrm{Hg}$, showing a typical hormetic response in both, $\mathrm{HN}$ and LN plants.

Due to the impact of $\mathrm{Hg}$ on the redox balance of plants, we analysed antioxidant APX and GR activities. APX activity augmented slightly in shoots of alfalfa plants exposed to $\mathrm{Hg}$, independently of the level of $\mathrm{NO}_{3}-$ (Fig. 5). Interestingly, root APX activity was higher in $\mathrm{HN}$ plants than LN ones, which increased concomitantly with $\mathrm{Hg}$ exposure; trend that was also found in LN plants but to a lower extent. On the other hand, shoot GR increased slightly under Hg stress, particularly in plants exposed to $30 \mu \mathrm{M} \mathrm{Hg}$, independently of the nitrogen nutritional status. Conversely, root GR activity of HN plants decreased with $6 \mu \mathrm{M} \mathrm{Hg}$ until it was completely inhibited with $30 \mu \mathrm{M} \mathrm{Hg}$. The inhibition of GR activity was stronger in plants grown with low $\mathrm{NO}_{3}-$ exposed to $6 \mu \mathrm{M} \mathrm{Hg}$, and was almost completely inhibited by $30 \mu \mathrm{M} \mathrm{Hg}$.

Due to the changes observed in the enzymatic activities, we studied possible alterations in the accumulation of NR, GR, APX and, additionally, the nitrate transporters NTR1.1 and NTR2.1 by Westernblot immunodetection (Fig. 6). Plants nourished with HN showed higher levels of NR than LN ones, especially in the shoots. NR expression also augmented under exposure to $\mathrm{Hg}$, with its highest accumulation in plants treated with $30 \mu \mathrm{M} \mathrm{Hg}$. We could not detect the nitrate transporters NTR2.1 and 
NTR1.1 in the shoot, implying that these transporters are meant to incorporate nitrate from the substrate and/or its transfer to the shoot (Feng et al. 2013; Bajgain et al. 2018). $\mathrm{NO}_{3}-$ enhanced modestly the amount of NTR2.1 in control HN plants, and then reached wales similar to control and Hg-treated LN plants. On the other hand, NTR1.1 was slightly lower in HN plants, independently of the $\mathrm{Hg}$ treatments. With regard to APX and GR redox enzymes, their amount did not change significantly in roots, but augmented in the root of $\mathrm{LN}$ and $\mathrm{HN}$ plants in the presence of $\mathrm{Hg}$. Interestingly, A second band of GR with higher mobility appeared in the shoot of plants exposed to $30 \mu \mathrm{M} \mathrm{Hg}$.

\section{Discussion}

The higher concentration of total $\mathrm{N}$ and NR activity in shoots compared to roots (c.a. 5-times) indicate that alfalfa plants assimilate $\mathrm{NO}_{3}-$ mostly in the shoot, in agreement with the behaviour of alfalfa plants at a vegetative development stage previously described (Arrese-lgor et al. 1991; Vance et al. 2009). HN treatment resulted in the concomitant increase in $\mathrm{NO}_{3}-$ concentration in roots and shoots, along with remarkably high NR activity and enzyme levels in shoots, compared with LN supplied plants. Such changes were expected, since NR regulation depends on the amount of available $\mathrm{NO}_{3}-$ (Campbell 1999; Krapp 2015). In fact, the limited amount of $\mathrm{NO}_{3}-$ in $\mathrm{LN}$ plants was reflected in lower chlorophyll content in plants grown with restricted $\mathrm{NO}_{3}-$. Indeed the large content of $\mathrm{N}$ observed in $\mathrm{HN}$ plants matches prevent chlorosis as it is known that chlorophyll concentration is a good $\mathrm{N}$ nutritional status indicator (Evans 1983; Houlès et al. 2007).

Under $\mathrm{Hg}$ exposure, the concentration of $\mathrm{NO}_{3}-$ and the amount of $\mathrm{N}$ decreased remarkably in shoots of $\mathrm{HN}$ plants, whereas only $30 \mu \mathrm{M} \mathrm{Hg}$ led to a significant diminution of $\mathrm{N}$ content under LN supply. Other toxic metals also decreased the levels of $\mathrm{N}$ and $\mathrm{NO}_{3}-$ supplied at similar doses and intervals as those used here, although little information is available at different levels of $\mathrm{N}$ nutrition: $\mathrm{N}$ and $\mathrm{NO}_{3}-$ concentration decreased in Cd-treated tomato (Chaffei et al. 2004) and rice (Hassan et al. 2005). In addition, $\mathrm{NO}_{3}$ - uptake and accumulation was severely compromised in bean plants (Gouia et al. 2000) and Arabidopsis (Mao et al. 2014; Vazquez et al. 2020). Moreover, Hernández et al. (1997) found a rapid $\left(24 \mathrm{~h}\right.$ ) impairment of $\mathrm{NO}_{3}-$ uptake and assimilation in pea plants exposed to 10 to $50 \mu \mathrm{M} \mathrm{Cd}$, reflected in a remarkable inhibition of NR.

It has been shown that NR activity was differently affected by metal stress, decreasing in Phaseolus vulgaris (Gouia et al. 2000), Arabidopsis (Mao et al. 2014) and tomato leaves (Chaffei et al. 2004) at doses above 10-100 $\mu \mathrm{M} \mathrm{Cd}$, and in Pisum sativum leaves after 24 to $72 \mathrm{~h}$ of exposure to $50 \mu \mathrm{M} \mathrm{Cd}$ (Hernández et al. 1997). Additionally, Chugh et al. (1992) reported that NR activity in Pisum sativum leaves was affected by Cd concentrations above $2.5 \mathrm{mM}$, and augmented significantly in leaves of Panicum maximum at similar levels of Cd (de Sousa Leite and Monteiro 2019). Similar increase of NR activity was observed in Silene cucubalus Zn-tolerant populations treated with $0.4 \mathrm{mM} \mathrm{Zn}$ (Mathys 1975). In our case, NR activity augmented remarkably in the root of plants exposed to $6 \mu \mathrm{M} \mathrm{Hg}$ with high $\mathrm{NO}_{3}{ }^{-}$, 
activation that also occurred in LN plants but to a lesser degree. However, NR activity dropped under acute stress, in plants treated with $30 \mu \mathrm{M} \mathrm{Hg}$ possibly as a consequence of cell poisoning (Van Assche and Clijsters 1990). On the other hand, NR activity was less affected in shoots, where changes were less pronounced, but increased significantly in the presence of $30 \mu \mathrm{M} \mathrm{Hg}$. Interestingly, the increase in NR activity was accompanied with an accumulation of NR enzyme, as we found by immunodetection, in agreement with the regulation of NR activity by de novo expression of the enzyme (Campbell 1999).

In consequence, $\mathrm{Hg}$ could lead to a remarkable unbalance of $\mathrm{NO}_{3}-$ in the plant, causing a higher proportion of $\mathrm{NO}_{3}-$ assimilation in the root under moderate stress. We tested possible changes in the levels of $\mathrm{NO}_{3}-$ transporters, as they are known to modulate the tolerance to $\mathrm{Cd}$ by controlling its xylem loading (Li et al. 2010). In addition, Cd apparently inhibits NTR1.1 and subsequently blocks $\mathrm{NO}_{3}-$ uptake (Mao et al. 2014), whereas also the plasma membrane NTR2.1 NO${ }_{3}^{-}$transporter seems to attenuate Cd uptake (Guan et al. 2021). However, in our experiments we did not observe meaningful changes in the amount of NTR2.1 or NRT1.1 due to Hg in LN alfalfa plants, where high affinity transporters should operate, although their regulation are complex and subjected to post-translational modifications (Wirth et al. 2007). In addition, we could only detect a minimal decrease of NRT2.1 in HN under Hg stress, which may contribute to the diminution observed in $\mathrm{NO}_{3}-$ uptake. Nevertheless, more profound and detailed future experiments must be performed to confirm these results, probably in combination with $\left[{ }^{15}{\mathrm{~N}] \mathrm{NO}_{3}-}^{-}\right.$ tracer experiments.

The concentration of $\mathrm{Hg}$ increased in a dose dependent manner, being accumulated basically in the root, as was described previously (Rellán-Álvarez et al. 2006; Sierra et al. 2008; Sobrino-Plata et al. 2009; Carrasco-Gil et al. 2011). Alfalfa plant is prone to restrict the movement of $\mathrm{Hg}$ to shoot by $\mathrm{Hg}$ immobilization in root, showing typical excluder behaviour (Briat and Lebrun 1999). Mercury is a rather immobile element that binds strongly with different components at the cell wall and biological membranes, mainly associated with proteins and carbohydrates in alfalfa and Marrubium vulgare (Hall 2002; Carrasco-Gil et al. 2011, 2013). Control plants grown with low and high $\mathrm{NO}_{3}{ }^{-}$accumulated a detectable level of $\mathrm{Hg}$ in shoot, probably due to the potential volatilization of $\mathrm{Hg}$ from the nutrient solution and deposition in leaves (Suszcynsky and Shann 1995).

Usually, supply of nitrogen fertilization results in higher accumulation of $\mathrm{Hg}, \mathrm{Zn}$ or $\mathrm{Cd}$ in plants cultivated in metal-polluted soils (Wångstrand et al. 2007; Barrutia et al. 2009; Gao et al. 2010; Carrasco-Gil et al. 2012). However, plants cultivated in hydroponic solutions or pots under controlled conditions experienced a metal dilution effect due to biomass increase, as was observed in Cd-treated Arabidopsis (Vazquez et al. 2020), soybean (Konotop et al. 2012), wheat (Yotsova et al. 2020), and Populus (Chen et al. 2011). Nevertheless, nitrogen nutritional influence depends on genotypes, phenology status and growth conditions, leading to conflicting results (Sarwar et al. 2010; Yang et al. 2016; Bi et al. 2020). For example, high $\mathrm{N}$ nutritional status increased root but slightly decreased shoot $\mathrm{Cd}$ concentrations in two rice genotypes (Du et al. 2009). We found enhanced accumulation of $\mathrm{Hg}$ under $\mathrm{LN}$, which cannot be explained solely in terms of a toxic metal dilution effect, as there were only significant differences in shoot biomass 
compared with high $\mathrm{NO}_{3}-$ grown plants. Therefore, some tolerance mechanisms should promote a decrease in $\mathrm{Hg}$ uptake in high $\mathrm{NO}_{3}-$ treated alfalfa, probably linked to improved $\mathrm{Hg}$ stress tolerance.

One possible mechanism could be the larger accumulation of hGSH in the roots of high $\mathrm{NO}_{3}-$ plants exposed to $6 \mu \mathrm{M} \mathrm{Hg}$, almost two-fold increase compared to low $\mathrm{NO}_{3}$ - plants (Table 1), which determine the tolerance to metal-induced oxidative stress (Hernández et al. 2015). However, under acute stress in plants treated with $30 \mu \mathrm{M} \mathrm{Hg}$ values were similar at both $\mathrm{NO}_{3}-$ nutritional status. hGSH and GSH are fundamental antioxidant biothiols required for metal tolerance: plants depleted of GSH or hGSH were more susceptible to oxidative damage induced by Hg and Cd stress (Sobrino-Plata et al. 2014a, b, 2021). hGSH and GSH are also the building blocks of PCs, biothiols that are able to form very stable complexes with $\mathrm{Hg}$ (Carrasco-Gil et al. 2011). Unfortunately, although we tried to analyse free PCs in our samples, we were unable to detect any of them in the different treatments performed. $\mathrm{Hg}$-PC or Hg-hPC complexes are extremely durable even when subjected to strong acidic extraction procedures (Sobrino-Plata et al. 2021). It is feasible that during the relatively long exposure time used in our experiments (one week) $\mathrm{Hg}$ bound and blocked thiol groups of PCs/hPCs preventing their reaction with Ellman's reagent and, therefore, their detection (Iglesia-Turiño et al. 2006).

Accumulation of $\mathrm{Hg}$ to high levels in roots led to significant induction of oxidative stress, whereas shoots were much less affected, matching previous observations (Ortega-Villasante et al. 2005). Apparently, antioxidant enzymes like GR and APX had higher activity in shoots, corresponding with concomitant accumulation detected by immunoblots, irrespective of the $\mathrm{NO}_{3}-$ nutritional status, and resembling the responses found in alfalfa with similar doses of $\mathrm{Hg}$ (Sobrino-Plata et al. 2009). Interestingly, roots of plants grown with low $\mathrm{NO}_{3}$ - suffered stronger $\mathrm{GR}$ activity inhibition when treated with $6 \mu \mathrm{M} \mathrm{Hg}$ than plants supplied with high $\mathrm{NO}_{3}-$, without meaningful changes of enzyme amount. Similar behaviour occurred in alfalfa grown in a Hg-polluted soils under greenhouse conditions, where plants nourished with nitrogen $\left(\mathrm{NH}_{4} \mathrm{NO}_{3}\right)$ were more tolerant and showed higher $\mathrm{GR}$ activity than plants only fertilized with $\mathrm{P}$ and K (Carrasco-Gil et al. 2012). In this sense, our group observed repeatedly that GR activity is an specific bioindicator of $\mathrm{Hg}$ toxicity in plant cells, which is inhibited to higher degree whenever plants are more susceptible to $\mathrm{Hg}$ (Sobrino-Plata et al. 2009, 2013, 2014b, 2021). However, under high $\mathrm{Hg}$ concentration $(30 \mu \mathrm{M})$ both $\mathrm{NO}_{3}-$ nutritional levels showed similar degree of damage, implying that above a certain threshold of $\mathrm{Hg}$ accumulation, the influence of low $\mathrm{NO}_{3}-$ nutrition was overridden. Finally, APX activity increased in response to $\mathrm{Hg}$, but independently to $\mathrm{NO}_{3}$ - nutritional status in shoots, while it increased to a higher degree in HN alfalfa plants than in LN ones. These results were basically in agreement with those described by Sobrino-Plata et al. (2009), who found a modest induction of APX in alfalfa plants grown in semi-hydroponic conditions. Induction of APX occurs under moderate Hg-stress, without changes in the amount of APX, probably owing to post-translational regulation mechanisms (Ortega-Villasante et al. 2007). 
In conclusion, high supply of $\mathrm{NO}_{3}-$ prevented toxic effects caused by $\mathrm{Hg}$, in the same manner that ameliorated damages observed mainly by $\mathrm{Cd}$ in different plant species. APX and GR activity increased (Chen et al. 2011), while lower lipid peroxidation and enhanced peroxidase and GR activity were described in Populus plants exposed to $\mathrm{Cd}$ (Bi et al. 2020). Similarly, wheat plants experienced lower oxidation stress and had improved photosynthetic efficiency in the presence of Cd (Yotsova et al. 2020), whereas there was strong induction of guaiacol peroxidase in Cd-exposed Arabidopsis (Vazquez et al. 2020). Finally, Matricaria chamomilla plants showed higher proportion of reduced GSH, improved APX activity and lower phenolic metabolism in Pb-stressed (Kováčik et al. 2020). Therefore, the $\mathrm{NO}_{3}$ - nutritional status of plants might be important to improve their tolerance to $\mathrm{Hg}$, in particular at moderate levels of $\mathrm{Hg}$ $(6 \mu \mathrm{M})$. However, more work is needed for a better understanding of the mechanisms of tolerance involved. Such research will help to optimise the use of plants in phytotechnologies to clean up polluted soils or stabilise them to avoid erosion and loss of fertility.

\section{Declarations}

\section{ACKNOWLEDGEMENTS}

This work was supported by Spanish Ministry of Science (Grants AGL2010-15151, AGL2014-53771-R and AGL2017-87591-R). We thank Paula Bueno-Vargas (UAM) for her technical assistance to prepare various plant protein extracts.

\section{References}

1. Arrese-Igor C, Garcia-Plazaola JI, Diaz A, Aparicio-Tejo PM (1991) Distribution of nitrate reductase activity in nodulated lucerne plants. Plant Soil 131:107-113. https://doi.org/10.1007/BF00010425

2. Bajgain $P$, Russell $B$, Mohammadi $M$ (2018) Phylogenetic analyses and in-seedling expression of ammonium and nitrate transporters in wheat. Sci Rep 8:1-13. https://doi.org/10.1038/s41598-01825430-8

3. Barrutia O, Epelde L, García-Plazaola Jl, et al (2009) Phytoextraction potential of two Rumex acetosa L. accessions collected from metalliferous and non-metalliferous sites: Effect of fertilization. Chemosphere 74:259-264. https://doi.org/10.1016/j.chemosphere.2008.09.036

4. Bi J, Liu X, Liu S, et al (2020) Microstructural and physiological responses to cadmium stress under different nitrogen forms in two contrasting Populus clones. Environ Exp Bot 169:103897. https://doi.org/10.1016/j.envexpbot.2019.103897

5. Briat JF, Lebrun M (1999) Plant responses to metal toxicity. Comptes Rendus l'Academie des Sci - Ser III 322:43-54. https://doi.org/10.1016/S0764-4469(99)80016-X

6. Campbell WH (1999) Nitrate reductase structure, function and regulation: Bridging the gap between biochemistry and physiology. Annu Rev Plant Physiol Plant Mol Biol 50:277-303. https://doi.org/10.1146/annurev.arplant.50.1.277 
7. Cargnelutti D, Tabaldi LA, Spanevello RM, et al (2006) Mercury toxicity induces oxidative stress in growing cucumber seedlings. Chemosphere 65:999-1006.

https://doi.org/10.1016/j.chemosphere.2006.03.037

8. Carrasco-Gil S, Alvarez-Fernández A, Sobrino-Plata J, et al (2011) Complexation of Hg with phytochelatins is important for plant $\mathrm{Hg}$ tolerance. Plant Cell Environ 34:778-791. https://doi.org/10.1111/j.1365-3040.2011.02281.x

9. Carrasco-Gil S, Estebaranz-Yubero M, Medel-Cuesta D, et al (2012) Influence of nitrate fertilization on $\mathrm{Hg}$ uptake and oxidative stress parameters in alfalfa plants cultivated in a Hg-polluted soil. Environ Exp Bot 75:16-24. https://doi.org/10.1016/j.envexpbot.2011.08.013

10. Carrasco-Gil S, Siebner H, LeDuc DL, et al (2013) Mercury localization and speciation in plants grown hydroponically or in a natural environment. Environ Sci Technol 47:3082-3090. https://doi.org/10.1021/es303310t

11. Chaffei C, Pageau K, Suzuki A, et al (2004) Cadmium toxicity induced changes in nitrogen management in Lycopersicon esculentum leading to a metabolic safeguard through an amino acid storage strategy. Plant Cell Physiol 45:1681-1693. https://doi.org/10.1093/pcp/pch192

12. Chen $L$, Han $Y$, Jiang $H$, et al (2011) Nitrogen nutrient status induces sexual differences in responses to cadmium in Populus yunnanensis. J Exp Bot 62:5037-5050. https://doi.org/10.1093/jxb/err203

13. Cho UH, Park JO (2000) Mercury-induced oxidative stress in tomato seedlings. Plant Sci 156:1-9. https://doi.org/10.1016/S0168-9452(00)00227-2

14. Chugh LK, Gupta VK, Sawhney SK (1992) Effect of cadmium on enzymes of nitrogen metabolism in pea seedlings. Phytochemistry 31:395-400. https://doi.org/https://doi.org/10.1016/00319422(92)90004-A

15. Clemens S, Palmgren MG, Krämer U (2002) A long way ahead: Understanding and engineering plant metal accumulation. Trends Plant Sci 7:309-315. https://doi.org/10.1016/S1360-1385(02)02295-1

16. de Sousa Leite T, Monteiro FA (2019) Nitrogen form regulates cadmium uptake and accumulation in Tanzania guinea grass used for phytoextraction. Chemosphere 236:124324.

https://doi.org/10.1016/j.chemosphere.2019.07.055

17. Du Q, Chen M, Zhou R, et al (2009) Cd toxicity and accumulation in rice plants vary with soil nitrogen status and their genotypic difference can be partly attributed to nitrogen uptake capacity. Rice Sci 16:283-291. https://doi.org/10.1016/S1672-6308(08)60092-X

18. Elbaz A, Wei YY, Meng Q, et al (2010) Mercury-induced oxidative stress and impact on antioxidant enzymes in Chlamydomonas reinhardtii. Ecotoxicology 19:1285-1293. https://doi.org/10.1007/s10646-010-0514-z

19. Esbrí JM, Bernaus A, Ávila M, et al (2010) XANES speciation of mercury in three mining districts Almadén, Asturias (Spain), Idria (Slovenia). J Synchrotron Radiat 17:179-186. https://doi.org/10.1107/S0909049510001925

20. Evans JR (1983) Nitrogen and photosynthesis in the flag leaf of wheat (Triticum aestivum L.). Plant Physiol 72:297-302. https://doi.org/10.1104/pp.72.2.297 
21. Feng H, Yan M, Fan X, et al (2013) Spatial expression and regulation of rice high-affinity nitrate transporters by nitrogen and carbon status. Sci Rep 282:844-856. https://doi.org/10.1038/s41598018-25430-8

22. Finkemeier I, Kluge C, Metwally A, et al (2003) Alterations in Cd-induced gene expression under nitrogen deficiency in Hordeum vulgare. Plant, Cell Environ 26:821-833. https://doi.org/10.1046/j.1365-3040.2003.01014.x

23. Gao X, Brown KR, Racz GJ, Grant CA (2010) Concentration of cadmium in durum wheat as affected by time, source and placement of nitrogen fertilization under reduced and conventional-tillage management. Plant Soil 337:341-354. https://doi.org/10.1007/s11104-010-0531-y

24. Gouia H, Habib Ghorbal M, Meyer C (2000) Effects of cadmium on activity of nitrate reductase and on other enzymes of the nitrate assimilation pathway in bean. Plant Physiol Biochem 38:629-638. https://doi.org/10.1016/S0981-9428(00)00775-0

25. Guan M, Chen M, Cao Z (2021) NRT2 . 1 , a major contributor to cadmium uptake controlled by highaffinity nitrate transporters. Ecotoxicol Environ Saf 218:112269.

https://doi.org/10.1016/j.ecoenv.2021.112269

26. Hall JL (2002) Cellular mechanisms for heavy metal detoxification and tolerance. J Exp Bot 53:1-11. https://doi.org/10.1093/jxb/53.366.1

27. Han FX, Su Y, Monts DL, et al (2006) Binding, distribution, and plant uptake of mercury in a soil from Oak Ridge, Tennessee, USA. Sci Total Environ 368:753-768. https://doi.org/10.1016/j.scitotenv.2006.02.026

28. Hassan MJ, Wang F, Ali S, Zhang G (2005) Toxic effect of cadmium on rice as affected by nitrogen fertilizer form. Plant Soil 277:359-365. https://doi.org/10.1007/s11104-005-8160-6

29. Hernandez LE, Carpena-Ruiz R, Garate A (1996) Alterations in the mineral nutrition of pea seedlings exposed to cadmium. J Plant Nutr 19:1581-1598

30. Hernández LE, Gárate A, Carpena-Ruiz R (1997) Effects of cadmium on the uptake, distribution and assimilation of nitrate in Pisum sativum. Plant Soil 189:97-106.

https://doi.org/10.1023/A:1004252816355

31. Hernández LE, Sobrino-Plata J, Montero-Palmero MB, et al (2015) Contribution of glutathione to the control of cellular redox homeostasis under toxic metal and metalloid stress. J. Exp. Bot. 66:29012911

32. Houlès V, Guérif M, Mary B (2007) Elaboration of a nitrogen nutrition indicator for winter wheat based on leaf area index and chlorophyll content for making nitrogen recommendations. Eur J Agron 27:111. https://doi.org/10.1016/j.eja.2006.10.001

33. Hussain S, Khaliq A, Noor MA, et al (2020) Metal Toxicity and Nitrogen Metabolism in Plants: An Overview. In: Datta R, Meena RS, Pathan SI, Ceccherini MT (eds) Carbon and Nitrogen Cycling in Soil. Springer Singapore, Singapore, pp 221-248

34. Iglesia-Turiño S, Febrero A, Jauregui O, et al (2006) Detection and quantification of unbound phytochelatin 2 in plant extracts of Brassica napus grown with different levels of mercury. Plant 
Physiol 142:742-749. https://doi.org/10.1104/pp.106.085068

35. Israr M, Sahi S V. (2006) Antioxidative responses to mercury in the cell cultures of Sesbania drummondii. Plant Physiol Biochem 44:590-595. https://doi.org/10.1016/j.plaphy.2006.09.021

36. Jiménez A, Hernández JA, Barceló AR, et al (1998) Mitochondrial and peroxisomal ascorbate peroxidase of pea leaves. Physiol Plant 104:687-692.

https://doi.org/https://doi.org/10.1034/j.1399-3054.1998.1040424.x

37. Konotop Y, Mészáros P, Spieß N, et al (2012) Defense responses of soybean roots during exposure to cadmium, excess of nitrogen supply and combinations of these stressors. Mol Biol Rep 39:1007710087. https://doi.org/10.1007/s11033-012-1881-8

38. Kováčik J, Dresler S, Wójciak-Kosior M, Babula P (2020) Uptake and phytotoxicity of lead are affected by nitrate nutrition and phenolic metabolism. Environ Exp Bot 178:104158. https://doi.org/10.1016/j.envexpbot.2020.104158

39. Krapp A (2015) Plant nitrogen assimilation and its regulation: a complex puzzle with missing pieces. Curr Opin Plant Biol 25:115-122. https://doi.org/10.1016/j.pbi.2015.05.010

40. Laemmli UK (1970) Cleavage of structural proteins during the assembly of the head of bacteriophage T4. Nature. https://doi.org/10.1038/227680a0

41. Li J, Fu Y, Pike SM, et al (2010) The Arabidopsis Nitrate Transporter NRT1 . 8 Functions in Nitrate Removal from the Xylem Sap and Mediates Cadmium Tolerance. 22:1633-1646. https://doi.org/10.1105/tpc.110.075242

42. Mao QQ, Guan MY, Lu KX, et al (2014) Inhibition of Nitrate Transporter 1 . 1-Controlled Nitrate Uptake Reduces Cadmium Uptake in Arabidopsis 1 [ C ][ W ]. 166:934-944. https://doi.org/10.1104/pp.114.243766

43. Mathys W (1975) Enzymes of heavy-metal-resistant and non-resistant populations of Silene cucubalus and their interaction with some heavy metals in vitro and in vivo. Physiol Plant 161-165

44. Ortega-Villasante C, Hernández LE, Rellán-Álvarez R, et al (2007) Rapid alteration of cellular redox homeostasis upon exposure to cadmium and mercury in alfalfa seedlings. New Phytol 176:96-107. https://doi.org/10.1111/j.1469-8137.2007.02162.x

45. Ortega-Villasante C, Rellan-Alvarez R, Del Campo FF, et al (2005) Cellular damage induced by cadmium and mercury in Medicago sativa. J Exp Bot 56:2239-2251. https://doi.org/10.1093/jxb/eri223

46. Patra M, Sharma A (2000) Mercury toxicity in plants. Bot Rev 66:379-422. https://doi.org/10.1007/BF02868923

47. Porra RJ (2002) The chequered history of the development and use of simultaneous equations for the accurate determination of chlorophylls $a$ and $b$. Photosynth Res 73:149-156. https://doi.org/10.1023/A:1020470224740

48. Ramón AM, Carpena Ruiz RO, Gárate A (1989) In vitro stabilization and distribution of nitrate reductase in tomato plants. Incidence of boron deficiency. J Plant Physiol 135:126-128. https://doi.org/https://doi.org/10.1016/S0176-1617(89)80237-8 
49. Rellán-Álvarez R, Ortega-Villasante C, Álvarez-Fernández A, et al (2006) Stress responses of Zea mays to cadmium and mercury. Plant Soil 279:41-50. https://doi.org/10.1007/s11104-005-3900-1

50. Sarwar N, Saifullah, Malhi SS, et al (2010) Role of mineral nutrition in minimizing cadmium accumulation by plants. J Sci Food Agric 90:925-937. https://doi.org/10.1002/jsfa.3916

51. Serrano N, Díaz-Cruz JM, Ariño C, Esteban M (2015) Recent contributions to the study of phytochelatins with an analytical approach. TrAC - Trends Anal. Chem. 73:129-145

52. Sharma SS, Dietz K-J (2009) The relationship between metal toxicity and cellular redox imbalance. Trends Plant Sci 14:43-50. https://doi.org/10.1016/j.tplants.2008.10.007

53. Shiyab S, Chen J, Han FX, et al (2009) Phytotoxicity of mercury in Indian mustard (Brassica juncea L.). Ecotoxicol Environ Saf 72:619-625. https://doi.org/10.1016/j.ecoenv.2008.06.002

54. Sierra MJ, Millán R, Esteban E (2008) Potential use of Solanum melongena in agricultural areas with high mercury background concentrations. Food Chem Toxicol 46:2143-2149. https://doi.org/10.1016/j.fct.2008.02.009

55. Sobrino-Plata J, Barón-Sola Á, Ortega-Villasante C, et al (2021) Sulphur and biothiol metabolism determine toxicity responses and fate of mercury in Arabidopsis. Environ Exp Bot 182: https://doi.org/10.1016/j.envexpbot.2020.104302

56. Sobrino-Plata J, Carrasco-Gil S, Abadía J, et al (2014a) The role of glutathione in mercury tolerance resembles its function under cadmium stress in Arabidopsis. Metallomics 6:356-366

57. Sobrino-Plata J, Herrero J, Carrasco-Gil S, et al (2013) Specific stress responses to cadmium, arsenic and mercury appear in the metallophyte Silene vulgaris when grown hydroponically. RSC Adv 3:4736-4744

58. Sobrino-Plata J, Meyssen D, Cuypers A, et al (2014b) Glutathione is a key antioxidant metabolite to cope with mercury and cadmium stress. Plant Soil 377:369-381. https://doi.org/10.1007/s11104013-2006-4

59. Sobrino-Plata J, Ortega-Villasante C, Laura Flores-Cáceres M, et al (2009) Differential alterations of antioxidant defenses as bioindicators of mercury and cadmium toxicity in alfalfa. Chemosphere 77:946-954. https://doi.org/10.1016/j.chemosphere.2009.08.007

60. Suszcynsky EM, Shann JR (1995) Phytotoxicity and accumulation of mercury in tobacco subjected to different exposure routes. Environ Toxicol Chem 14:61-67. https://doi.org/https://doi.org/10.1002/etc.5620140108

61. Van Assche F, Clijsters H (1990) Effects of metals on enzyme activity in plants. Plant Cell Environ 13:195-206. https://doi.org/https://doi.org/10.1111/j.1365-3040.1990.tb01304.x

62. Vance CP, Heichel GH, Finkemeier I, et al (2009) Phytoextraction potential of two Rumex acetosa L. accessions collected from metalliferous and non-metalliferous sites: Effect of fertilization. Plant Soil 277:259-264. https://doi.org/10.1016/j.chemosphere.2008.09.036

63. Vazquez A, Recalde L, Cabrera A, et al (2020) Does nitrogen source influence cadmium distribution in Arabidopsis plants? Ecotoxicol Environ Saf 191:110163. https://doi.org/10.1016/j.ecoenv.2020.110163 
64. Wångstrand H, Eriksson J, Oborn l" (2007) Cadmium concentration in winter wheat as affected by nitrogen fertilization. Eur J Agron 26:209-214. https://doi.org/10.1016/j.eja.2006.09.010

65. Wirth J, Chopin F, Santoni V, et al (2007) Regulation of root nitrate uptake at the NRT2.1 protein level in Arabidopsis thaliana. J Biol Chem 282:23541-23552. https://doi.org/10.1074/jbc.M700901200

66. Wong MH (2003) Ecological restoration of mine degraded soils, with emphasis on metal contaminated soils. Chemosphere 50:775-780. https://doi.org/https://doi.org/10.1016/S00456535(02)00232-1

67. Yang Y, Xiong J, Chen R, et al (2016) Excessive nitrate enhances cadmium (Cd) uptake by upregulating the expression of OsIRT1 in rice (Oryza sativa). Environ Exp Bot 122:141-149. https://doi.org/10.1016/j.envexpbot.2015.10.001

68. Yoneyama T, Suzuki A (2019) Exploration of nitrate-to-glutamate assimilation in non-photosynthetic roots of higher plants by studies of $15 \mathrm{~N}$-tracing, enzymes involved, reductant supply, and nitrate signaling: A review and synthesis. Plant Physiol Biochem 136:245-254. https://doi.org/10.1016/j.plaphy.2018.12.011

69. Yotsova E, Dobrikova A, Stefanov M, et al (2020) Effects of cadmium on two wheat cultivars depending on different nitrogen supply. Plant Physiol Biochem 155:789-799. https://doi.org/10.1016/j.plaphy.2020.06.042

70. Zhou ZS, Huang SQ, Guo K, et al (2007) Metabolic adaptations to mercury-induced oxidative stress in roots of Medicago sativa L. J Inorg Biochem 101:1-9. https://doi.org/10.1016/j.jinorgbio.2006.05.011

\section{Figures}


A

SHOOT
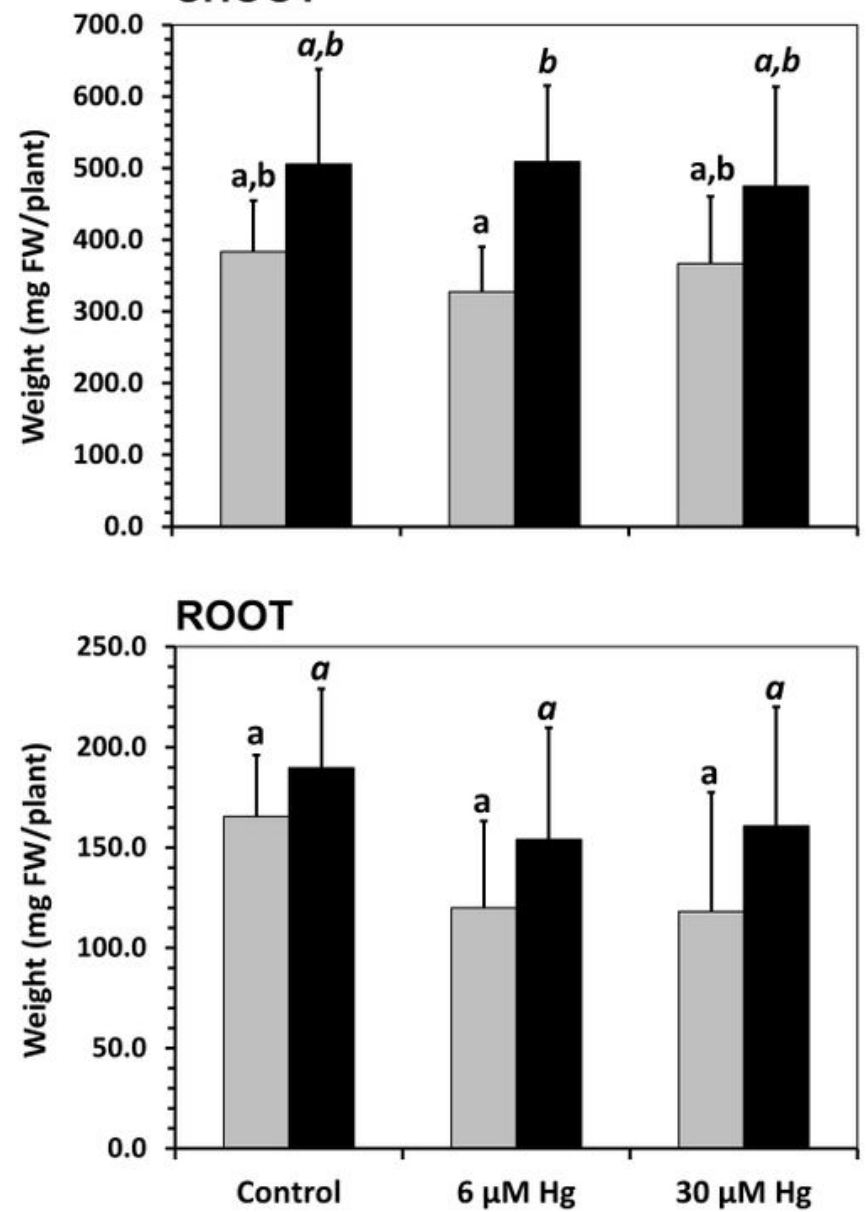

SHOOT
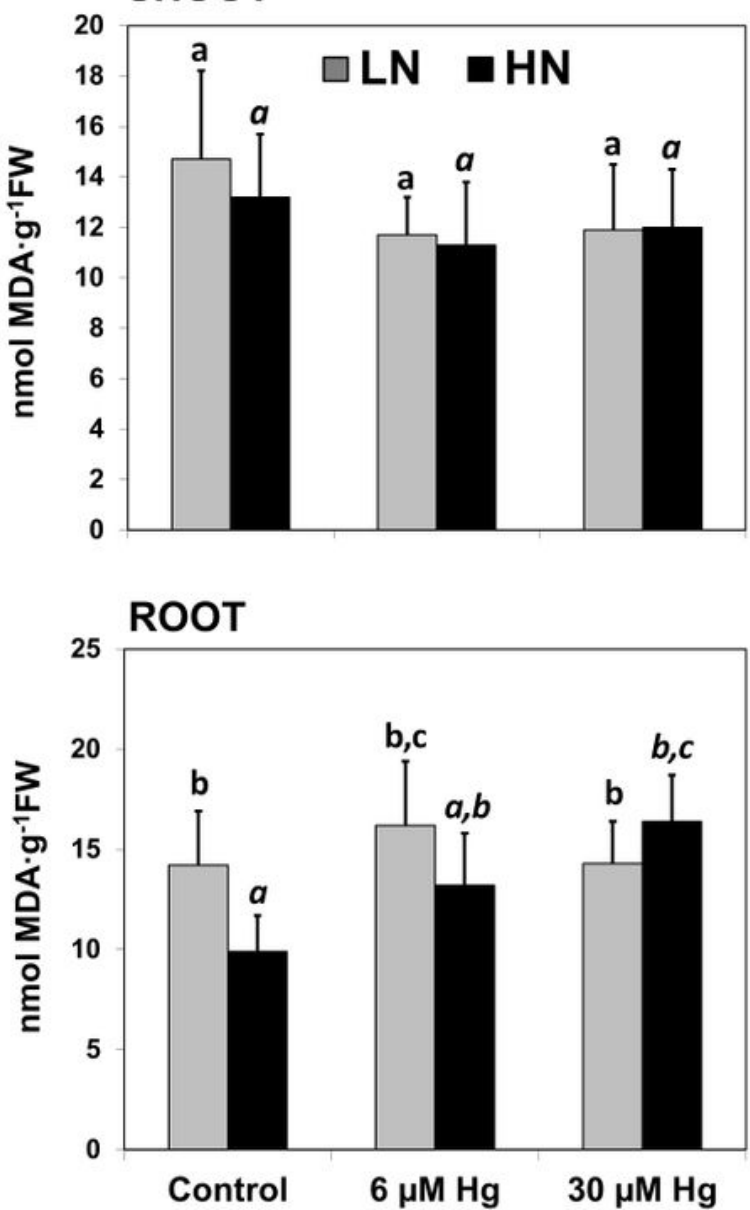

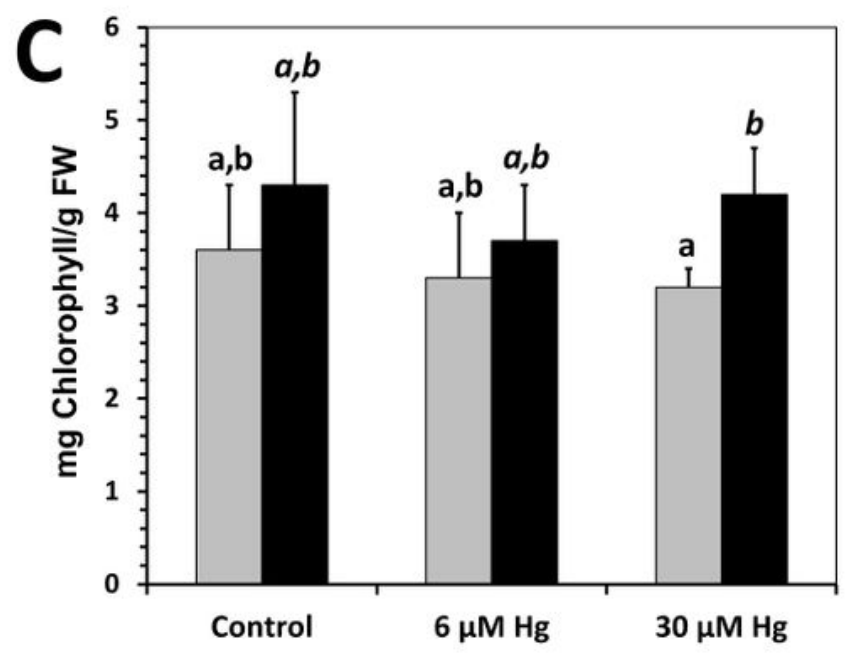

Figure 1

Physiological parameters of stress to $\mathrm{Hg}$ in alfalfa. A) Fresh weight (mg plant-1), B) lipid peroxidation as MDA subproduct concentration ( $\mathrm{nmol} \cdot \mathrm{g}-1 \mathrm{FW}$ ), and C) total chlorophyll (Chla + Chlb) concentration (mg.g-1 FW) in shoots or roots of Medicago sativa grown in low NO3- (LN, 2 mM) and high NO3- (HN, $12 \mathrm{mM}$ ) treated with 0 (control), 6 and $30 \mu \mathrm{M} \mathrm{Hg}$ for 7 days. Data are average of three independent 

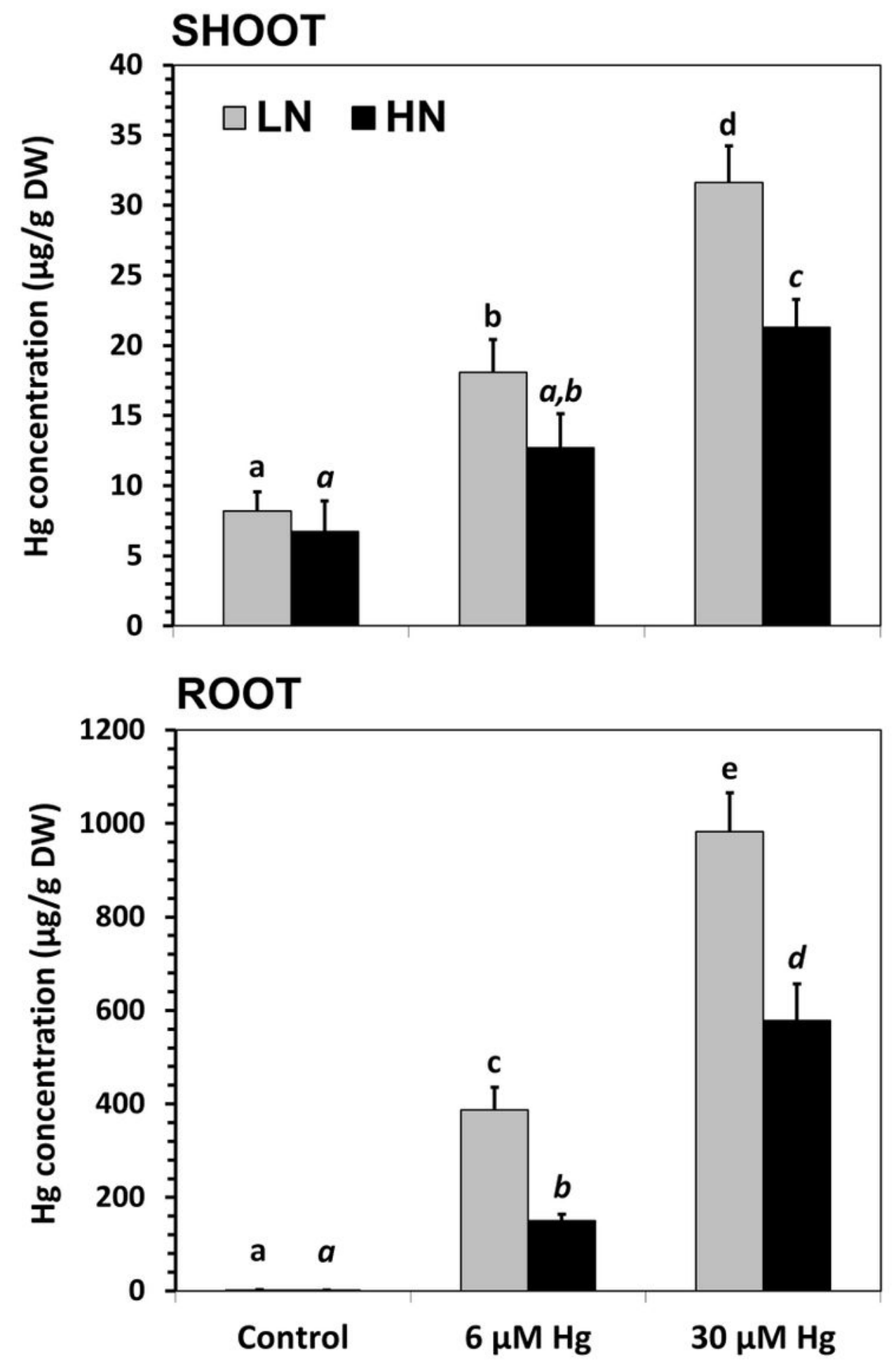

Figure 2

Total $\mathrm{Hg}(\mu \mathrm{g} \cdot \mathrm{g}-1 \mathrm{DW})$ in shoot and root of Medicago sativa grown in low NO3- (LN, $2 \mathrm{mM}$ ) and high NO3- (HN, $12 \mathrm{mM}$ ) treated with 0 (control), 6 and $30 \mu \mathrm{M} \mathrm{Hg}$ for 7 days. Data are average of five 
independent replicates $( \pm S D)$. Different letters denote significant differences between treatments at $p<0.05$. (Regular letter for $L N$ and italics for $H N$ ).
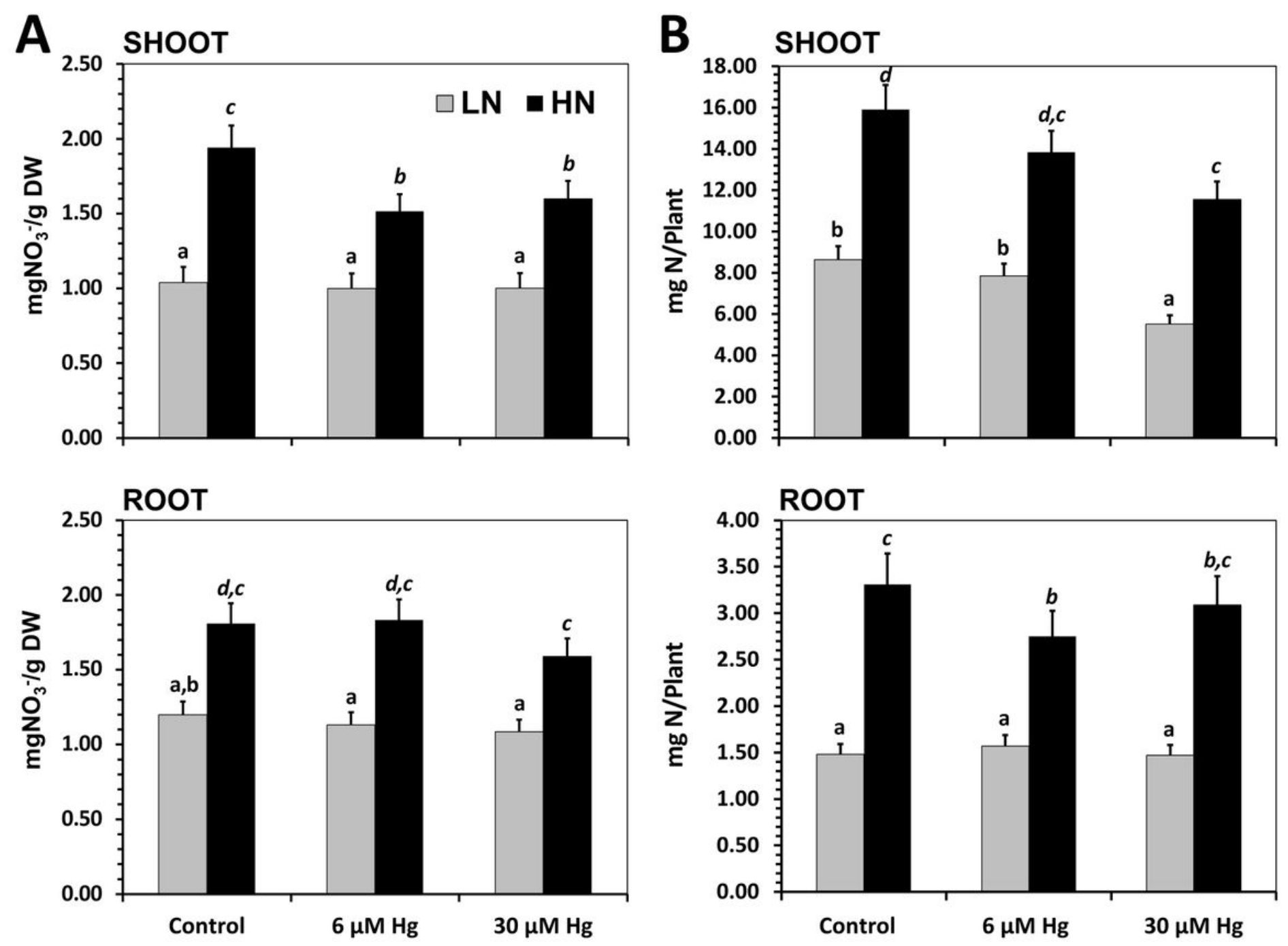

Figure 3

A) Nitrate concentration (mg NO3-·g-1 FW), and B) nitrogen accumulation (mg NH4+ plant-1) in shoot and root of Medicago sativa grown in low NO3- (LN, $2 \mathrm{mM})$ and high NO3- $(\mathrm{HN}, 12 \mathrm{mM})$ treated with 0 (control), 6 and $30 \mu \mathrm{M} \mathrm{Hg}$ for 7 days. Data are average of at least three independent assays ( \pm SD). Different letters denote significant differences between treatments at $p<0.05$. (Regular letter for $L N$ and italics for $\mathrm{HN}$ ). 

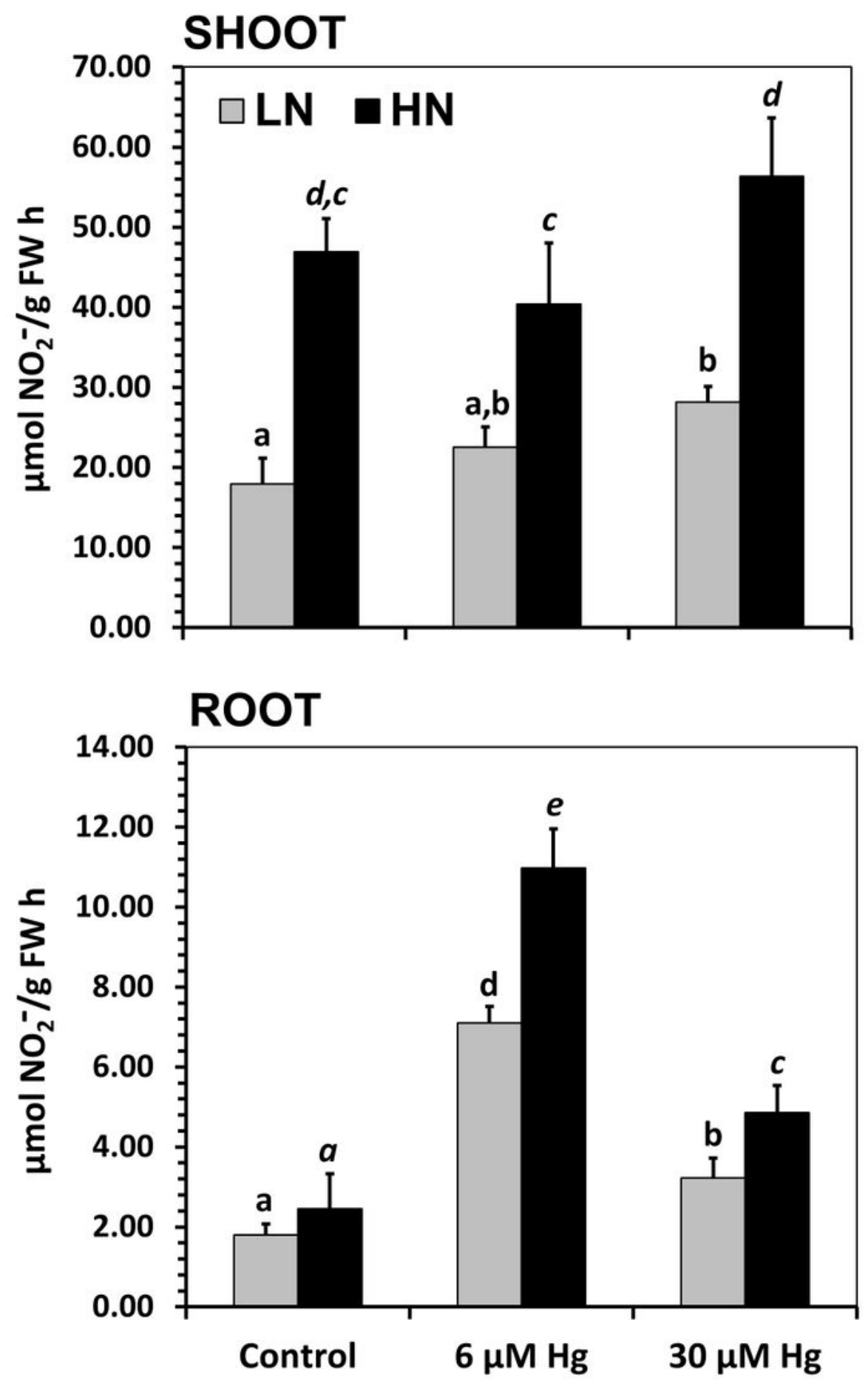

Figure 4

Nitrate reductase activity (NR) (nmol NO2- g-1 FW h-1) in shoot and root of Medicago sativa grown in low NO3- (LN, $2 \mathrm{mM}$ ) and high NO3- (HN, $12 \mathrm{mM}$ ) treated with 0 (control), 6 and $30 \mu \mathrm{M}$ of Hg for 7 days. Data are average of at least three independent replicates $( \pm S D)$. Different letters denote significant differences between treatments at $p<0.05$. (Regular letter for $L N$ and italics for $H N$ ). 


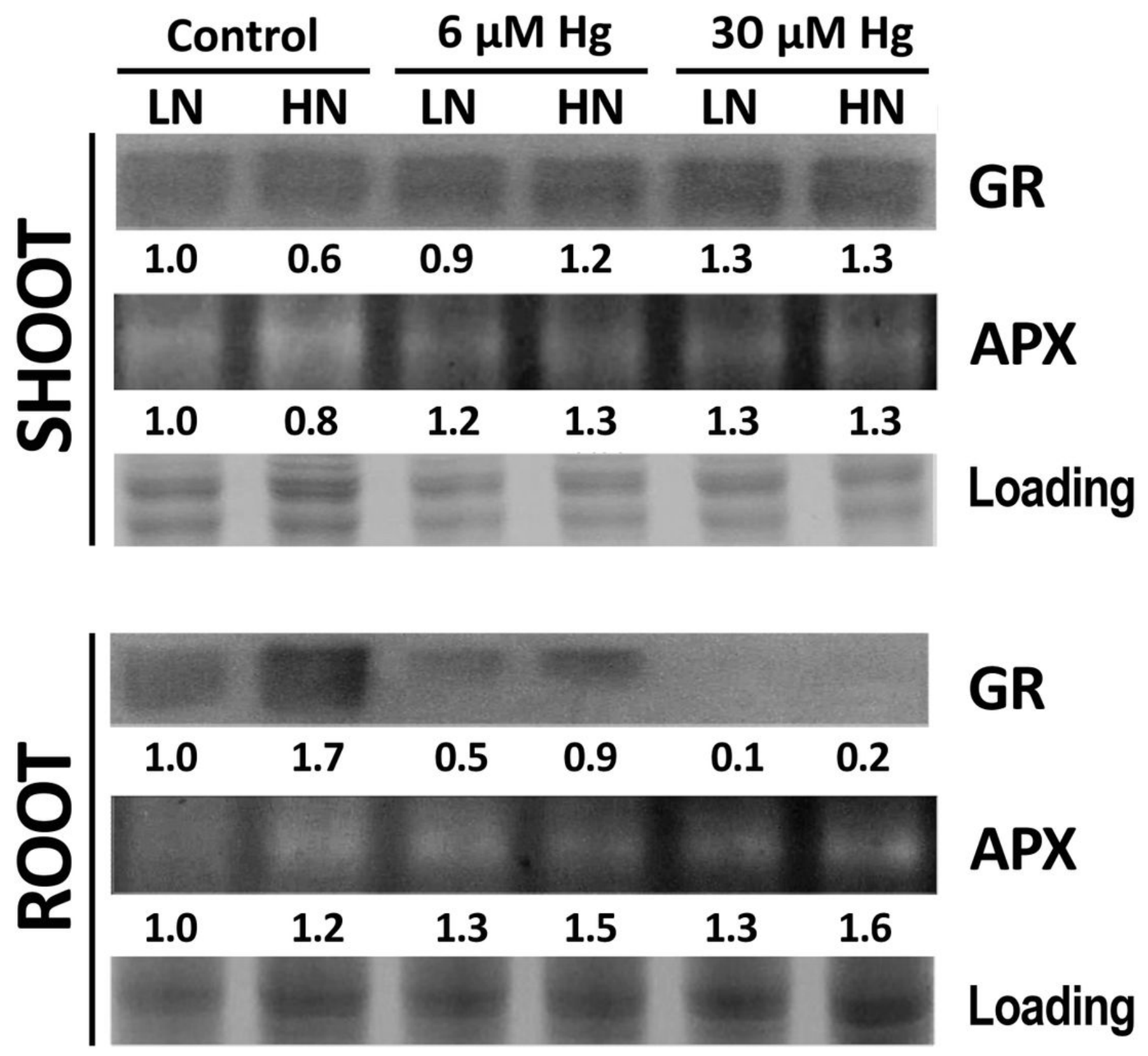

Figure 5

Effect of mercury on in gel glutathione reductase (GR) and ascorbate peroxidase (APX) activity in shoot and root of Medicago sativa grown in low NO3- (LN, $2 \mathrm{mM})$ and high NO3- $(\mathrm{HN}, 12 \mathrm{mM})$ treated with 0 (control), 6 and $30 \mu \mathrm{M} \mathrm{Hg}$ for 7 days. Numbers below the band represent the relative fold-change against the LN control, normalized relative to the intensity of Coomassie blue protein staining (loading). 

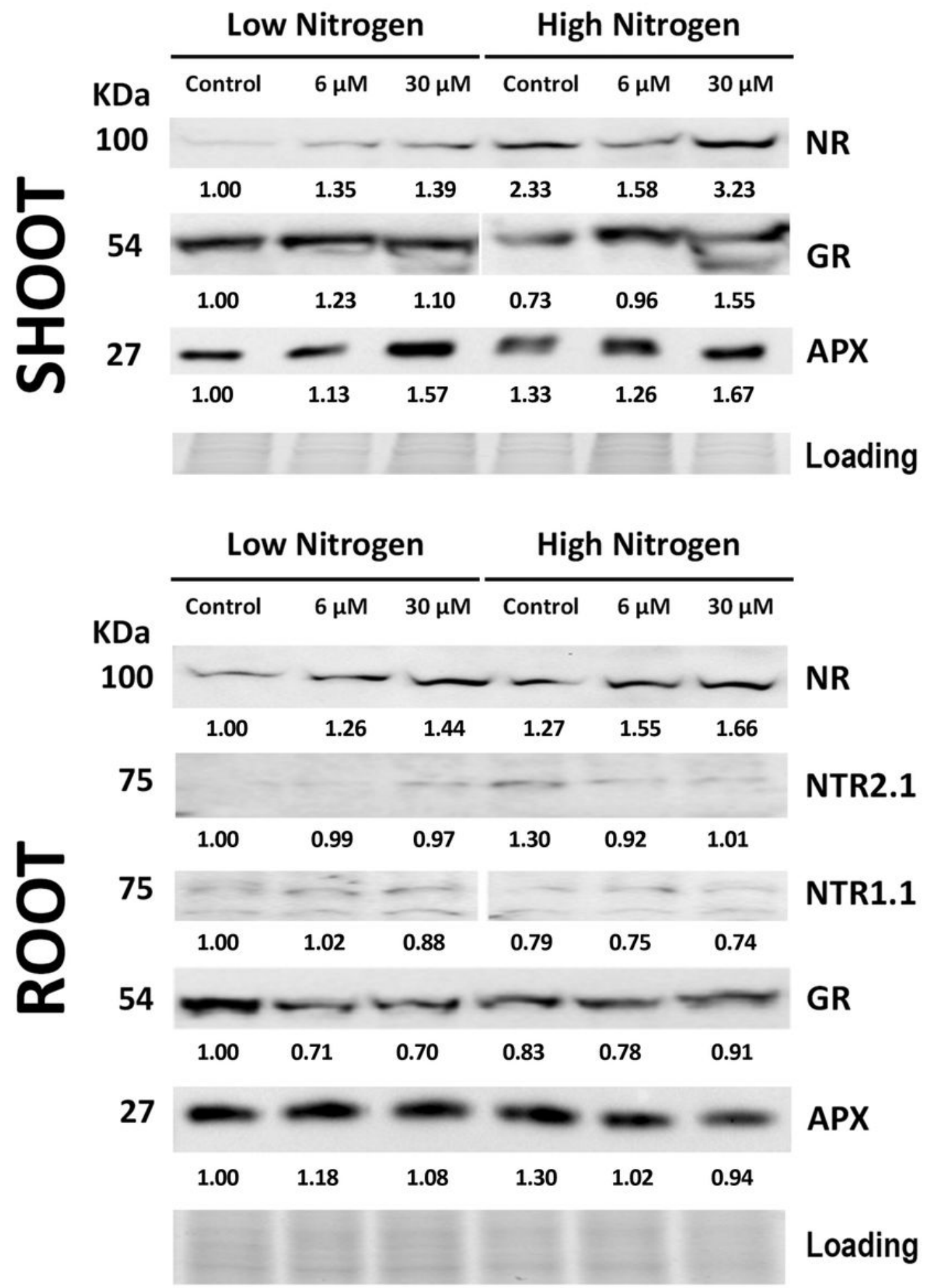

Figure 6

Western-blot immunodetection using specific antibodies against nitrate reductase (NR), nitrate transporters (NTR2.1 and NTR1.1), glutathione reductase (GR), ascorbate peroxidise (APX) in protein extracts prepared from shoots and roots of Medicago sativa grown in low nitrogen (2 mM NO3-) and high nitrogen (12 mM NO3-), treated with 0 (control), 6 and $30 \mu \mathrm{M} \mathrm{Hg}$ for 7 days. Numbers below the 
bands represent the relative fold-change against the $\mathrm{LN}$ control, normalized relative to the intensity of Coomassie blue protein staining (loading). 